\title{
HUBUNGAN INTERAKSI SOSIAL DENGAN KUALITAS HIDUP LANSIA DI UNIT PELAYANAN TERPADU (UPTD) GRIYA WERDHA KOTA SURABAYA TAHUN 2017
}

\author{
Dina Andesty ${ }^{1}$, Fariani Syahrul ${ }^{2}$ \\ ${ }^{1,2}$ Departemen Epidemiologi, Fakultas Kesehatan Masyarakat \\ Universitas Airlangga \\ Alamat korespondensi:Dina Andesty \\ E-mail: dinaandesty@gmail.com
}

\begin{abstract}
The number of elderly in many countries is increasing, including in Indonesia. Along with the increasing number of elderly, many problems will be experienced by the elderly such as psychological disorders, pathological disorders on physical conditions, access to health services that is difficult to obtain and less social support from family or friends. Lack of social support will affect the social interaction of elderly. Social interaction can have a positive impact on the quality of life because the social interaction of the elderly do not feel lonely, therefore social interaction must be developed and maintained in the elderly group. The purpose of this study is to analyze the social interaction with the quality of life of the elderly in UPTD Griya werdha Surabaya. This study used cross sectional study design. The study population is all elderly in UPTD Griya Werdha Surabaya City. The sample size is as much as 52 elderly are taken using simple random sampling method. The dependent variable of the research is the quality of life of the elderly and the independent variable is social interaction. The research instrument used WHOQOL-OLD questionnaire. The result of the research shows taht there is relationship between social interaction with quality of life of elderly in UPTD Griya Werdha Surabaya ( p-value $=0.017$ ). The conclusion of this study is social interaction related to the quality of life of the elderly, the worse the social interaction of the elderly, the lower the quality of life. The suggestion from this research is to increase social interaction of elderly by increasing daily activity of elderly in order to often gather and interact with each other.
\end{abstract}

Keywords: Social interaction, quality of life, elderly, WHOQOL-OLD

\begin{abstract}
ABSTRAK
Jumlah lanjut usia di banyak negara semakin lama semakin meningkat jumlahnya,termasuk di Indonesia. Seiring dengan jumlah lansia yang meningkat, banyak permasalahan yang akan dialami oleh lansia seperti gangguan psikis, gangguan patologis pada kondisi fisik, akses pelayanan kesehatan yang susah diperoleh dan berkurangnya dukungan sosial yang diperoleh dari keluarga atau teman. Kurangnya dukungan sosial akan mempengaruhi interaksi sosial lansia. Interaksi sosial dapat berdampak posistif terhadap kualitas hidup karena dengan adanya interaksi sosial maka lansia tidak akan merasa kesepian, oleh sebab itu interaksi sosial harus tetap dipertahankan dan dikembangkan pada kelompok lansia. Tujuan penelitian ini adalah menganalisis interaksi sosial dengan kualitas hidup lansia di UPTD Griya werdha Kota Surabaya. Penelitian ini menggunakan desainstudi cross sectional.Populasi penelitian adalah semua lansia di UPTD Griya Werdha Kota Surabaya. Besar sampel adalah sebanyak 52 lansia diambil menggunakan metode simple random sampling. Variabel dependent penelitian adalah kualitas hidup lansia dan variabel independent adalah interaksi sosial. Instrumen penelitian menggunakan kuesioner WHOQOL-OLD. Hasil penelitian menunjukan ada hubungan antarainteraksi sosial dengan kualitas hidup lansia di UPTD Griya Werdha Kota Surabaya ( $p$-value $=0,017$ ). Kesimpulan dari penelitian ini adalah interaksi sosial berhubungan dengan kualitas hidup lansia, semakin buruk interaksi sosial lansia maka semakin rendah pula kualitas hidupnya. Saran dari penelitian ini adalah meningkatkan interaksi sosial lansia dengan meningkatkan aktifitas atau kegiatan harian lansia agar dapat sering berkumpul dan saling berinteraksi satu sama lain.
\end{abstract}

Kata kunci: Interaksi sosial, kualitas hidup, lansia, WHOQOL-OLD 


\section{PENDAHULUAN}

Dampak dari kemajuan ilmu pengetahuan dan teknologi terutama di bidang kesehatan, berhasil untuk menurunkan angka kematian bayi dan anak dan memperlambat kematian sehingga berdampak pada peningkatan jumlah lansia. Peningkatan jumlah lansia ini juga diikuti dengan usia harapan hidup yang juga meningkat (Yuliati, Baroya, \& Ririyanti, 2014).

Penduduk usia lanjut semakin meningkat jumlahnya di banyak negara termasuk di Indonesia. Jumlah usia lanjut diatas 60 tahun diprediksi akan meningkat jumlahnya menjadi $20 \%$ pada tahun 2015 2050. Indonesia berada di posisi keempat setelah Cina, India, dan Jepang. Hasil Susenas tahun 2014 menginformasikan bahwa jumlah usia lanjut di Indonesia adalah sebanyak 20,24 juta jiwa atau $8,03 \%$. Hal tersebut bila dibandingkan dengan hasil Sensus tahun 2010 maka ada peningkatan jumlah lansia yaitu 18,1 juta jiwa atau 7,6\% (Kemenkes RI, 2011).

Pusat Data dan Informasi Kemenkes RI pada tahun 2015 juga menginformasikan bahwa 5 provinsi dengan sebaran penduduk lansia terbesar adalah Yogyakarta sebesar 13,4\%, Jawa Tengah sebesar 11,8\%, Jawa Timur sebesar 11,5\%, Bali sebesar 10,3\%, dan Sulawesi Utara sebesar 9,7\%, sedangkan sebaran penduduk lansia terendah adalah Papua sebesar 2,8\% (Kemenkes RI, 2015).

Provinsi Jawa Timur berada di posisi ke tiga dengan jumlah lansia terbanyak dan kota Surabaya merupakan salah satu kota besar dengan persentase pertumbuhan lanjut usia yang cukup tinggi bila dibandingkan dengan kota-kota besar di Indonesia. Berdasarkan data Badan Pusat Statistik (BPS) Provinsi Jawa Timur (2016) jumlah lanjut usia 60 tahun ke atas di kota Surabaya mencapai $7,9 \%$ dimana usia harapan hidup kota Surabaya mencapai 71 tahun.

BKKBN (2012) mengatakandengan meningkatnya jumlah populasi dan angka usia harapan hidup usia lanjut mengakibatkan berbagai masalah seperti masalah kesehatan, psikologis, dan sosial ekonomi akan dirasakan oleh lansia.Selain itu hal tersebut juga akan mempengaruhi kesejahteraan lansia baik dari segi fisik, mental dan sosial, dimana apabila masalah tersebut tidak ditangani dengan baik maka ditakutkan akan berkembang menjadi masalah yang sangat kompleks (Notoadmojo, 2008).

Salamah (2005) juga menambahkan bahwa jumlah lansia yang semakin meningkat, akan mengakibatkan lansia banyak mengalami masalah-masalah seperti kurangnya mendapatkan pendidikan, akses kesehatan sulit diperoleh, tidak ada jaminan hari tua, dukungan sosial dari keluarga atau teman akan berkurang. Oleh karena itu, tak jarang lansia akan mengalami masalahpsikologis maupun fisik, dan gangguan patologis yang mengakibatkan lansia mudah terserang berbagai macam penyakit.

Masalah psikologis pada lansia merupakan salah satu proses penuaan yang akan dialami oleh semua lansia. Lansia akan mengalami perubahan psikologis seperti short term memory, frustasi, kesepian, takut kehilangan kebebasan, takut menghadapi kematian, perubahan keinginan, depresi, dan kecemasan. Masalah psikologis pada lansia biasanya terjadi karena transisi peran pada lingkungan sosial, kehilangan, perubahan pada fisiologis dan kematian (Maryam, $\mathrm{dkk}, 2008)$. Perubahan psikologis yang dialami oleh lansia akan mengakibatkan lansia secara perlahan menarik diri dari hubungan dengan masyarakat sekitar sehingga dapat mempengaruhi interaksi sosial. Berkurangnya interaksi sosial pada lansia dapat menyebabkan perasaan terisolir, sehingga lansia memilih menyendiri dan merasa terisolasi dan akhirnya depresi, maka hal ini dapat mempengaruhi kualitas hidup lansia (Maryam, dkk, 2008).

\begin{tabular}{rrr}
\multicolumn{2}{c}{ Interaksi sosial merupakan } \\
hubungan sosial yang
\end{tabular}


mempengaruhi antar individu yang terjadi di masyarakat yang berlangsung sepanjang hidupnya. Interaksi sosial dapat berdampak positif terhadap kualitas hidup karena dengan adanya interaksi sosial maka lansia tidak merasa kesepian, oleh sebab itu interaksi sosial harus tetap dipertahankan dan dikembangkan pada kelompok lansia. Lanjut usia yang dapat terus menjalin interaksi sosial dengan baik adalah lansia yang dapat mempertahankan status sosialnya berdasarkan kemampuan bersosialisasi (Noorkasiani, 2009).

Adanya perubahan kualitas hidup yang dialami oleh lansia biasanya cenderung mengarah ke arah yang kurang baik. Biasanya hal tersebut berhubungan dengan lingkungan sosial ekonomi lansia seperti berhenti bekerja karena pensiun, kehilangan anggota keluarga yang dicintai dan teman, dan ketergantungan kebutuhan hidup serta adanya penurunan kondisi fisik yang disebabkan oleh faktor usia. Perubahan-perubahan tersebut menjadi suatu kendala dalam menentukan tingkat kesejahteraan lansia, karena adanya penurunan dalam pemenuhan kebutuhan hidup (Wikananda, 2015).

Perubahan-perubahan yang terjadi pada lansia akan mengakibatkan menurunnya peran sosial lansia dan juga menurunnya derajat kesehatan akibatnya lansia akan kehilangan pekerjaan dan merasa menjadi individu yang kurang mampu. Hal tersebut akan mempengaruhi interaksi sosial lansia karena lansia menarik diri dari hubungan dengan masyarakat sekitar secara perlahan. Interaksi sosial yang buruk pada lansia dapat mempengaruhi kualitas hidup lansia dimana hal tersebut akan menyebabkan lansia merasa terisolir sehingga lansia jadi suka menyendiri dan akan menyebabkan lansia depresi (Samper, Pinontoan, \& Katuuk, 2017).

World Health Organization Quality of Life (WHOQOL) mendefinisikan kualitas hidup adalah suatu persepsi individu yang berkaitan dengan tujuan, harapan, standar, dan perhatian dalam kehidupannya di masyarakat dalam konteks budaya dan sistem nilai yang ada. Hal ini memberikan pengertian bahwa kualitas hidup dipengaruhi oleh hubungan lansia dengan lingkungan sekitar, kondisi fisik lansia, kondisi psikososial lansia dan tingkat kemandirian lansia (Suprajitno, 2004).

Pada umumnya kualitas hidup lansia menjadi menurun karena pada masa usia lanjut biasanya lansia akan mengalami keterbatasan dan ketidakmampuan dalam melakukan suatu hal. Untuk meningkatkan kualitas hidup lansia dibutuhkan perawatan dimana peran keluarga sangat dibututhkan karena merupakan unit terkecil dari masyarakat (Demartoto, 2007).

Salah satu faktor yang dapat mempengaruhi kualitas hidup lansia adalah lingkungannya terutama lingkungan tempat tinggal. Perbedaan lingkungan tempat tinggal lansia akan dapat mempengaruhi lansia untuk beradaptasi. Penelitian ini dilakukan di panti jompo tepatnya di UPTD Griya Werdha Surabaya.UPTD Griya Werdha adalah panti jompo milik pemerintah dimana lansia sudah tidak perlu membayar untuk tinggal dan fasilitas yang didapat lansia cukup lengkap dari aspek kesehatan dimana selalu ada pemeriksaan kesehatan secara rutin, selain itu lansia juga difasilitasi dengan berbagai macam kegiatan agar lansia tidak merasa bosan. Fasilitas-fasilitas yang didapat lansia di UPTD Griya Werda seharusnya dapat meningkatkan kualitas hidup lansia dan juga dapat meningkatkan interaksi sosial karena lansia dapat berkumpul dengan sesama lansia di UPTD Griya Werdha setiap hari. Namun kenyataannya, beberapa penelitian mengatakan bahwa lansia yang tinggal di panti memiliki kualitas hidup yang rendah. Putri (2014) mengatakan bahwa lansia yang tinggal di panti dari domain interaksi sosial memiliki kualitas hidup yang kurang karena kegagalan lansia itu sendiri dalam lingkungannya dan perubahan peran sosial yang terjadi, sedangkan yang tinggal bersama keluarga sebagian besar memiliki 
kualitas hidup yang cukup dari segi layanan kesehatan, aktifitas sehari-hari dan interaksi sosialnya bersama keluarga, tetangga, dan masyarakat sekitar.

Perbedaan kualitas hidup dari domain interaksi sosial ini bisa saja terjadi karena kesulitan lansia dalam beradaptasi dengan lingkungan yang baru, yang mana lansia biasanya tinggal bersama keluarga dan masyarakat luas. Oleh karena itu tujuan dari penelitian ini adalah menganalisis interaksi sosial dengan kualitas hidup lansia di UPTD Griya Werdha Kota Surabaya.

\section{METODE PENELITIAN}

Jenis penelitian adalah observasional analitik dengan rancang bangun penelitian adalah desain studi cross sectional. Penelitian dilakukan di UPTD Griya werdha Kota Surabaya yang terletak di jalan Jambangan Baru Tol 15A Jambangan. Penelitian dilakukan pada bulan November - Desember 2017.

Populasi penelitian adalah semua lansia di UPTD Griya Werdha kota Surabaya yang berumur 60 tahun keatas dengan sampel sebesar 52 sampel.Teknik pengambilan sampel menggunakan simple random sampling. Variabel dependen penelitian adalah kualitas hidup lansia dan variabel independen adalah interaksi sosial. Instrumen yang digunakan dalam penelitian ini adalah instrumen kualitas hidup dari WHO (2004) yaitu WHOQOLOLD yang terdiri dari 24 item pertanyaan yang dibagi menjadi 6 domain.

Data primer penelitian diperoleh dari hasil wawancara menggunakan kuesioner dimana data primer ini terdiri dari data karakteristik lansia yang terdiri dari usia, jenis kelamin, tingkat pendidikan, dan status pernikahan, serta kualitas hidup lansia. Data sekunder penelitian meliputi jumlah lansia dan status kesehatan lansia yang diperoleh dari catatan medis lansia di UPTD Griya Werdha Kota Surabaya. Data yang telah diperoleh kemudian kemudian dilakukan pengolahan data dengan dengan editing, coding, dan scoring.

Penelitian ini menggunakan analisis univariat untuk menghitung distribusi frekuensi dan persentase dari tiap variabel, dan analisis bivariat untuk menganalisis hubungan antara variabel dependen dan independen dengan menggunakan uji statistik chi square dengan $\alpha=5 \%$.

\section{HASIL}

\section{Distribusi Lansia berdasarkan Karakteristik Lansia}

Distribusi lansia berdasarkan usia di UPTD Griya wedha Kota Surabayasebagian besar berada pada kategori usia 60-74. Usia terendah lansia adalah 60 tahun dan tertinggi 86 tahun dengan rata-rata umur lansia yaitu 72,83 . Pada umumnya kualitas hidup menurun seiring dengan meningkatnya usia karena terdapat penurunan fisik, perubahan mental, dan perubahan psikososial (Darmojo, 2009).

Distribusi lansia berdasarkan jenis kelamin di UPTD Griya wedha Kota Surabaya sebagian besar lansia berjenis kelamin perempuan. Laki-laki dan perempuan memiliki perbedaan dalam peran serta akses dan kendali terhadap berbagai sumber sehingga kebutuhan atau hal-hal yang penting bagi laki-laki dan perempuan juga akan berbeda. Hal ini mengindikasikan adanya perbedaan aspekaspek kehidupan dalam hubungannya dengan kualitas hidup pada laki-laki dan perempuan.

Pada variabel tingkat pendidikan, lansia dikelompokkan menjadi kategori rendah dengan tingkat pendidikan tidak sekolah, SD, SMP, dan kategori tinggi dengan tingkat pendidikan SMA dan Perguruan Tinggi. Distribusi lansia berdasarkan tingkat pendidikan di UPTD Griya Werdha Kota Surabaya hampir semua lansia memiliki kategori tingkat pendidikan yang rendah. Pendidikan dapat mempengaruhi kualitas hidup karena tingkat pendidikan seseorang sangat 
menentukan kemudahan seseorang dalam menerima setiap pembaharuan serta perpengaruh pada kemampuan mengelola informasi.

Tabel 1. Distribusi Frekuensi Karakteristik Lansia Di UPTD Griya Werdha Kota Surabaya Tahun 2017

\begin{tabular}{llcc}
\hline Variabel & Kategori & n & \% \\
\hline Usia & $75-90$ & 23 & 44,2 \\
& $60-74$ & 29 & 55,8 \\
Jenis & Laki-laki & 22 & 42,3 \\
Kelamin & Perempuan & 30 & 57,7 \\
Pendidikan & Rendah & 43 & 82,7 \\
& Tinggi & 9 & 17,3 \\
Status & Janda/Duda & 17 & 32,7 \\
Pernikahan & Tidak & 8 & 15,4 \\
& Menikah & & \\
& Menikah & 27 & 51,9 \\
\hline
\end{tabular}

Distribusi lansia berdasarkan status pernikahan di UPTD Griya Werdha Kota Surabaya menunjukkan bahwa sebagian besar lansia memiliki status menikah. Walaupun lansia memiliki status menikah tetapi pada kenyataannya banyak lansia yang menikah tidak tinggal bersama pasangannya di panti, beberapa ada yang pasangannya ikut bersama anak mereka dan ada yang pisah kota. Status pernikahan memberikan hubungan yang kuat terhadap status kualitas hidup lansia. Hal ini berkaitan dengan adanya dukungan dari pasangan hidup bagi lansia. Lansia yang masih terikat pernikahan akan memiliki status kualitas yang lebih baik.

\section{Distribusi Lansia Berdasarkan Penyakit Kronis yang diderita Lansia}

Distribusi lansia berdasarkan penyakit kronis yang diderita lansia di UPTD Griya Werdha Kota Surabaya menunjukkan bahwa sebagian besar lansia memiliki penyakit kronis. Penyakit kronis berperan dalam kemunduran kesehatan yang berangsur-angsur memburuk dan sering terjadi pada usia lanjut yang menyebabkan menurunnya kualitas hidup terkait ketidakmampuan dan keterbatasan fisik lansia.

Tabel 2. Distribusi Penyakit yang diderita Lansia di UPTD Griya Werdha Kota Surabaya tahun 2017

\begin{tabular}{ccc}
\hline Penyakit kronis & $\mathbf{N}$ & $\mathbf{( \% )}$ \\
\hline Ada & 40 & 76,9 \\
Tidak ada & 12 & 23,1 \\
Total & 52 & 100 \\
\hline
\end{tabular}

\section{Distribusi Lansia Berdasarkan Status Kualitas Hidup}

Kualitas hidup lansia diukur menggunakan instrument WHOQOL-OLD dimana kategori kualitas hidup dibagi menjadi 3 yaitu rendah, sedang, dan tinggi. Kategori rendah apabila skor kualitas hidup lansia setelah ditotalkan dan di transform skornya adalah 0-33, kualitas hidup sedang apabila skornya 34-66, dan kualitas hidup tinggi apabila skornya 67100. Distribusi lansia berdasarkan status kualitas hidup di UPTD Griya Werdha Kota Surabaya menunjukkan bahwa sebagian besar lansia memiliki kualitas hidup yang rendah. Perbedaan lingkungan tempat tinggal lansiaakan dapat mempengaruhi lansia untuk beradaptasi. Lansia akan merasakan berbeda saat tinggal di panti dan saat tinggal di rumah dikarenakan lansia yang tinggal di panti harus menerima orang-orang dan lingkungan yang baru.

Tabel 3. Distribusi Lansia Berdasarkan Status Kualitas Hidup di UPTD Griya Werdha Kota Surabaya tahun 2017

\begin{tabular}{ccc}
\hline Status Kualitas Hidup & n & \% \\
\hline Rendah & 28 & 53,8 \\
Sedang & 5 & 9,6 \\
Tinggi & 19 & 36,5 \\
Total & 52 & 100 \\
\hline
\end{tabular}




\section{Distribusi Lansia Berdasarkan Domain Status Kualitas Hidup}

Status kualitas hidup diukur menggunakan instrumen kualitas hidup dari WHO yaitu WHOQOL-OLD. Enam domain dalam instrumen WHOQOL-OLD yaitu domain kemampuan sensori terdiri dari kemunduran alat indra, penilaian terhadap fungsi sensorik, kemampuan dalam melakukan aktivitas, dan kemampuan untuk berinteraksi (Nugroho, 2008). Domain otonomi terdiri dari kebebasan dalam mengambil keputusan, menentukan masa depan, melakukan halhal yang diinginkan, kebebasan untuk dihargai. Domain aktifitas pada masa lampau, kini, dan yang akan datang terdiri dari hal-hal yang diharapkan, pencapaian keberhasilan, penghargaan yang diterima, pencapaian dalam kehidupan. Domain interaksi sosial terdiri dari penggunaan waktu, tingkat aktivitas, partisipasi pada kegiatan masyarakat. Domian kematian dan keadaan terminal meliputi jalannya/caranya meninggal, mengontrol akhir hidup, ketakutan akan akhir hidup, merasakan sakit pada akhir hidup. Domain persahabatan dan cinta kasih terdiri dari persahabatan dalam kehidupan, cinta dalam kehidupan, kesempatan untuk mencintai, dan kesempatan untuk dicintai (Rawiyah, 2014).

Setiap domain kualitas hidup pada instrumen WHOQOL-OLD dibagi menjadi kategori buruk, cukup, dan baik. Kategori buruk didapatkan apabila nilai skor adalah 0-33, kategori cukup apabila skornya 3466 , dan kategori baik apabila skornya 67100. Total skor diperoleh dari 24 item pertanyaan pada instrument WHOQOLOLD.

Tabel 4. Distribusi Status Kualitas Hidup Lansia Berdasarkan Domain Kualitas Hidup di UPTD Griya Werdha Kota Surabaya tahun 2017

\begin{tabular}{|c|c|c|c|c|c|c|c|c|}
\hline \multirow{2}{*}{ Domain kualitas hidup } & \multicolumn{2}{|c|}{ Buruk } & \multicolumn{2}{|c|}{ Cukup } & \multicolumn{2}{|c|}{ Baik } & \multicolumn{2}{|c|}{ Total } \\
\hline & $\mathbf{n}$ & $\%$ & $\mathbf{n}$ & $\%$ & $\mathbf{n}$ & $\%$ & $\mathbf{n}$ & $\%$ \\
\hline Kemampuan sensori & 16 & 30,8 & 16 & 30,8 & 20 & 38,5 & 52 & 100 \\
\hline Otonomi & 28 & 53,8 & 11 & 21,2 & 13 & 25 & 52 & 100 \\
\hline $\begin{array}{l}\text { Aktifitas pada masa lampau, } \\
\text { kini, dan yang akan datang }\end{array}$ & 24 & 46,2 & 18 & 34,6 & 10 & 19,2 & 52 & 100 \\
\hline Partisipasi sosial & 27 & 51,9 & 10 & 19,2 & 15 & 28,8 & 52 & 100 \\
\hline $\begin{array}{l}\text { Kematian dan Keadaan } \\
\text { Terminal }\end{array}$ & 19 & 36,5 & 12 & 23,1 & 21 & 40,4 & 52 & 100 \\
\hline Persahabatan dan cinta kasih & 25 & 48,1 & 22 & 21,2 & 16 & 30,8 & 52 & 100 \\
\hline
\end{tabular}

Tabel 5. Hubungan Interaksi Sosial dengan Kualitas Hidup Lansia di UPTD Griya Werdha Kota Surabaya tahun 2017

\begin{tabular}{|c|c|c|c|c|c|c|c|c|c|c|}
\hline \multirow{3}{*}{$\begin{array}{c}\text { Interaksi } \\
\text { Sosial }\end{array}$} & \multicolumn{6}{|c|}{ Kualitas Hidup } & \multirow{2}{*}{\multicolumn{2}{|c|}{ Total }} & \multirow{3}{*}{$x^{2}$} & \multirow{3}{*}{$p$ value } \\
\hline & \multicolumn{2}{|c|}{ Rendah } & \multicolumn{2}{|c|}{ Sedang } & \multicolumn{2}{|c|}{ Tinggi } & & & & \\
\hline & $\mathbf{n}$ & $\%$ & $\mathbf{n}$ & $\%$ & $\mathbf{n}$ & $\%$ & $\mathbf{n}$ & $\%$ & & \\
\hline Buruk & 21 & 77,8 & 1 & 3,7 & 5 & 18,5 & 27 & 100 & & \\
\hline Cukup & 4 & 40 & 1 & 10 & 5 & 50 & 10 & 100 & 8,123 & 0,017 \\
\hline Baik & 3 & 20 & 3 & 20 & 9 & 60 & 15 & 100 & & \\
\hline
\end{tabular}




\section{Hubungan Interaksi Sosial dengan Kualitas Hidup Lansia}

Hubungan interaksi sosial dengan kualitas hidup lansia di UPTD Griya Werdha Kota Surabaya tahun 2017 menunjukkan bahwa lansia yang memiliki status interaksi sosial yang buruk sebagian besar memiliki kualitas hidup yang rendah. Hasil penenelitian lebih lanjut didapatkan hasil bahwa teradapat hubungan antara interaksi sosial dengan kualitas hidup lansia di UPTD Griya Werdha Kota Surabaya tahun 2017.

Bertambahnya usia membuat lansia mengalami kemunduran dalam berinteraksi, lansia secara perlahan-lahan mulai melepaskan diri dari kehidupan sosialnya atau menarik diri dari pergaulan sekitarnya sehingga mengakibatkan kualitas hidupnya menurun.

\section{PEMBAHASAN}

\section{Gambaran Karakteristik Lansia}

Hasil penelitian diketahui bahwa sebagian besar lansia berada pada kelompok usia elderly (60-74 tahun) dengan rata-rata usia lansia 72,83. Data sensus penduduk pada tahun 2010 menginformasikan bahwa jumlah lanjut usia 60 tahun ke atas di kota surabaya mencapai 7,9\% dimana usia harapan hidup kota Surabaya mencapai 71 tahun. Hasil penelitian ini sesuai dengan usia harapan hidup di Surabaya dimana usia harapan hidup lansia di Surabaya berada pada rentang usia 60-74 tahun. Hal tersebut juga sesuai dengan usia harapan hidup di Indonesia yaitu 72 tahun (Kemenkes RI, 2015).

Kelompok usia very old (lebih dari 90 tahun) pada penelitian ini tidak dijumpai karena dengan bertambahnya usia, maka penurunan fungsi tubuh dan daya tahan fisik akan menurun, sehingga menyebabkan lansia akan mudah terserang penyakit yang dipengaruhi juga oleh perubahan dalam struktur dan fungsi sel, jaringan, dan sistem organ. Selain itu lansia juga akan mudah terserang infeksi dan komplikasi penyakit lainnya apabila memiliki kekebalan tubuh yang buruk dan status gizinya kurang sehingga risiko kematianakan meningkatkan.

Semua lansia di UPTD Griya Werdha Kota Surabaya merupakan lansia yang berumur diatas 60 tahun dikarenakan syarat yang ditetapkan oleh UPTD Griya Werdha dimana lansia yang diterima adalah lansia yang berumur 60 tahun keatas karena merujuk pada pengertian lansia yang ditetapkan oleh UU no.13 tahun 1998 tentang kesejahteraan lanjut usia yang menyatakan bahwa lanjut usia adalah seseorang yang telah berusia 60 tahun keatas.

Hasil penelitian menunjukkan bahwa penghuni UPTD Griya Werdha Kota Surabaya didominasi oleh lansia perempuan. Statistik di Indonesia pun menyatakan bahwa populasi lansia diatas 60 tahun didominasi oleh wanita (Kemenkes RI, 2015). Hal ini juga sesuai dengan jumlah lansia di Kota Surabaya dimana lansia perempuan lebih banyak $(8,15 \%)$ dibandingkan lansia laki-laki $(7,63 \%)$. Banyaknya lansia perempuan pada penelitian ini juga terjadi karena dari data populasi lansia di UPTD Griya Werdha Surabaya, lansia berjenis kelamin perempuan memang jumlah nya lebih banyak dibandingkan laki-laki.

Hasil penelitian menunjukkan bahwa hampir sebagian lansia di UPTD Griya Werdha Kota Surabaya tahun 2017 memiliki kategori tingkat pendidikan yang rendah. Hal ini sesuai dengan data Susenas tahun 2012 yang mengatakan bahwa masih banyak lansia yang berpendidikan rendah, dikarenakan lebih dari separuh penduduk lansia di Indonesia yang tidak pernah sekolah dan tidak tamat SD (Kemenkes RI, 2013).

Data lansia di UPTD Griya Werdha juga menunjukkan bahwa lansia yang berada di UPTD Griya Werdha merupakan lansia yang terlantar dan dilaporkan oleh warga dan Liponsos (Lingkungan Pondok Sosial). Lansia yang dilaporkan warga dan 
Liponsos di UPTD Griya Werdha biasanya merupakan lansia yang tidak tinggal lagi bersama keluarganya dan tidak memiliki pekerjaan. Hal ini dapat menunjukkan sosial ekonomi lansia yang berada di UPTD Griya Werdha Kota Surabaya berada pada sosial ekonomi menengah ke bahwah.Status sosial ekonomi lansia di UPTD Griya Werdha yang menengah ke bawah ini dapat mempengaruhi pendidikan lansia dimana hal tersebut memungkinkan lansia untuk tidak mendapatkan pendidikan yang baik sehingga memiliki pendidikan yang rendah.

Pendidikan merupakan suatu proses yang dapat mempengaruhi perilaku seseorang dan dengandemikian makan akan menimbulkan perubahanperilaku pada diri orang tersebut. Jadi dapat dikatakan bahwa seseorang dapat menerima informasi kesehatan dengan baik apabila memiliki pendidikan yang tinggi, dan sebaliknya seseorang dengan pendidikan yang rendah akan susah untuk orang tersebut menerima informasi kesehatan (Mubarak, 2006).

$$
\text { Distribusi frekuensi lansia }
$$

berdasarkan status pernikahan di UPTD Griya Werdha Kota Surabayamenunjukkan bahwa lansia paling banyak memiliki status Menikah. Menurut Susenas tahun 2012, sebagian besar lansia masih memiliki status menikah $(57,81 \%)$, sedangkan sisanya berstatus duda atau janda $(41,28 \%)$ dan tidak menikah $(0,91 \%)$.

Menurut penelitian Suristiani (2013) yang berjudul Analisis Kualitas hidup lansia di Kabupaten Mojokerto mengatakan bahwa status pernikahan mempengaruhi kualitas hidup lansia. Hal ini berkaitan dengan adanya dukungan pasangan hidup bagi pasien sehingga pasien yang masih terikat pernikahan akan memiliki status kualitas yang lebih baik.

Lansia di UPTD Griya Werdha Kota Surabaya walaupun banyak yang berstatus menikah, tetapi masih banyak lansia yang tidak tinggal bersama dengan pasangannya di UPTD Griya Werdha. Hal ini bisa terjadi karena biasanya lansia yang ditemukan terlantar hanya seorang diri dan tidak bersama pasangannya, selain itu ada beberapa lansia yang pasangannya tinggal bersama anaknya, dan juga terpisah kota sehingga lansia tersebut sendirian berada di UPTD Griya Werdha walaupun statusnya menikah.

\section{Distribusi Lansia Berdasarkan Penyakit Kronik yang Diderita}

Hasil penelitian didapatkan bahwa sebagian besar lansia memiliki penyakit kronik yang diderita. Adanya penyakit kronik pada populasi lansia biasanya terjadi karena faktor umur yang menyebabkan ketahanan tubuh lansia melemah dan mudah diserang berbagai macam penyakit (Wikananda, 2015).

Masih banyaknya lansia yang menderita penyakit kronik di UPTD Griya Werdha Surabaya selain disebabkan faktor umur bisa jadi karena faktor sosial ekonomi dan tingkat pendidikan lansia yang rendah. Lansia yang sebelumnya tidak tinggal di panti kurang memperhatikan tentang kondisi kesehatan mereka saat sendirian. Hal ini dapat terjadi karena kurangnya kesadaran dan pengetahuan lansia yang bisa diakibatkan karena tingkat pendidikan lansia yang rendah dan karena lansia tidak mempunyai ekonomi yang baik sehingga tidak bisa memeriksakan diri ke pelayanan kesehatan.

Lansia dapat menikmati hal-hal paling penting yang terjadi dalam hidupnya apabila memiliki kesehatan yang baik dan hal tersebut juga bisa menjadi ukuran dalam menentukan kualitas kehidupan lansia, kualitas hidup lansia akan semakin baik apabila lansia memiliki kesehatan yang baik pula dan sebaliknya lansia dengan kesehatan yang buruk maka kualitas hidupny akan semakin rendah.

Lansia yang memiliki masalah kesehatan juga akan mengurangi kemampuannya untuk bersosialisasi dengan lingkungan, dan hal tersebut juga akan mengurangi dukungan sosial yang 
diterima lansia dari sesama lansia (Azwan, dkk, 2015).

Lansia di UPTD Griya Werdha Kota Surabaya yang memiliki penyakit kronik memiliki keterbatasan fisik untuk berinteraksi sosial dengan sesama lansia. Mereka lebih banyak menghabiskan waktu di tempat tidur dibandingkan dengan keluar kamar untuk berkumpul dengan teman-teman lainnya.

\section{Hubungan Interaksi Sosial dengan Kualitas Hidup Lansia}

Hasil penelitian menunjukkan bahwa lansia yang memiliki hubungan sosial yang buruk dan cukup sebagian besar memiliki kualitas hidup yang rendah dan sebaliknya lansia yang memiliki kualitas hidup yang tinggi, memiliki hubungan sosial yang baik. Hasil analisis juga didapatkan bahwa nilai $p=0,017$ sehingga nilai $p$ kurang $\alpha$ menunjukkan bahwa ada hubungan antara interaksi sosial dengan kualitas hidup lansia di UPTD Griya Werdha Kota Surabaya (Siregar, 2013)

Hasil penelitian sesuai dengan penelitian Putri (2015) yang mengatakan bahwa lansia yang tinggal di panti memiliki kualitas hidup yang kurang dari aspek hubungan sosial sedangkan lansia yang tinggal bersama keluarga memiliki kualitas hidup cukup. Hasil penelitian lebih lanjut didapatkan hasil bahwa tempat tinggal mempengaruhi kualitas hidup lansia dari domain hubungan sosial. Lansia yang timggal di rumah dipengaruhi oleh dukungan keluarga dan masyarakat sehingga lansia akan mengalami perubahan yang positif terhadap kehidupan dan sebaliknya lansia akan mengalami perubahan yang negatifbila dukungan keluarga dan masyarakat yang diterima kurang (Potter\&Perry, 2005).

Rantepadang (2012) menyebutkan bahwa terdapat hubungan antara interaksi sosial dengan kualitas hidup lansia karenainteraksi sosial lansia yang baik akan menghasilkan kualitas hidup yang baik. Sanjaya dan Rusdi (2012) menyatakan bahwa untuk meningkatkan kualitas hidup lansia maka lansia harus memiliki interaksi sosial yang baik sehinggalansia tidak akan merasa kesepian dalam hidupnya.

Buruknya interaksi sosial lansia di UPTD Griya Werdha Kota Surabaya bisa diakibatkan karena lansia merasa kegiatan atau aktivitas yang bisa dilakukan di UPTD Griya Werdha Kota Surabaya sangat sedikit. Sebenarnya UPTD Griya Werdha sudah mempunyai programprogram untuk lansia yang dijadwalkan setiap hari. Program-program tersebut adalah pemeriksaan kesehatan, sharing lansia, games untuk lansia, pelatihan keterampilan seperti membuat sabun cuci piring dan hand scrub, senam lansia, dan jalan-jalan pagi lansia. Berdasarkan observasi peneliti, selain karena beberapa lansia merasa kurang dengan kegiatan di UPTD Griya Werdha, beberapa lansia lainnya lebih memilih untuk diam dikamar dan tidak mengikuti program-program yang telah ada. Hal ini mengakibatkan lansia membatasi interaksinya dengan penghuni lain karena lebih banyak menghabiskan waktu dikamar dan hanya diam di tempat tidur serta hanya berinteraksi dengan teman-teman yang hanya berada dikamar dan tidak berinteraksi dengan teman-teman lansia yang berada di kamar yang lain.

Interaksi sosial merupakan proses di mana terjadinya komunikasi antar individu atau antar kelompok dan berkaitan dengan aktitas sosial yang dilakukan dengan orang lain di masyarakat. Biasanya derajat kesehatan dan kemampuan fisik lansia akan menurun sehingga mengakibatkan interaksi sosial lansia menurun dan lansiaakan menghindar dari hubungan dengan orang lain (Hardywinoto, 2005)

Pada umumnya lansia akan mengalami penurunan dalam berinteraksi pada hari tuanya. Oleh karena itu lansia akan merasakan kesulitan dalam bersosialisasi, hal ini juga diakibatkan karena faktor usia. Lansia akan 
mendapatkan perasaan memiliki dalam kelompok apabila interaksi sosial yang dimiliki lansia baik sehingga bisa membuat lansia bisa saling berbagi cerita, berbagi minat dan berbagi perhatian antar satu sama lain, serta lansia dapat melakukan aktivitas secara bersama-sama. Selain itu lansia yang dapat berkumpul bersama dengan orang seusianya dapat saling menyemangati satu sama lain dan berbagi mengenai masalahnya karena dengan berbagi antara satu sama lain, maka akan berdampak terhadap sosial psikologis lansiasepertimenurunnya beban pikiran lansia dan lansia tidak akan merasakan kesepian (Sanjaya \& Rusdi, 2012).

Dukungan sosial dari lingkungan sekitar lansia merupakan interaksi sosial yang berdampak positif pada kesejahteraan emosional lansia dan kesehatan fisik serta diprediksi dapat menurunkan risiko kematian. Pada saat usia lanjut interaksi sosial cenderung menurun yang disebabkan oleh kerusakan kognitif, kematian teman, dan fasilitas hidup (Estelle dkk, 2006). Supraba (2015) mengatakan bahwa interaksi sosial berperan penting utnuk mentoleransi kondisi kesepian yang ada dalam kehidupan sosial lansia. Lansia yang yang dapat berinteraksi dengan baikseperti berinteraksidengan tetangga dan masyarakat di sekitarnya serta bisa mengikuti kegiatan yang ada di daerah nya berada, maka akan mendapatkan dukungan sosial yang baik pula dari lingkungannya dan apabila penyesuaian diri lansia tersebut tidak baik karena kurangnya interaksi dengan linkungan di sekitar lanisa maka dukungan sosial yang di dapatkan lanjut usia juga pasti tidak baik. Dukungan sosial sangat berhubungan erat dengan penyesuaian diri lansia karena dapat mempengaruhi kehidupan lansia baik di kehidupan yang sekarang ataupun yang akan datang (Kaplan dan Saddock, 2007).

\section{SIMPULAN}

Lansia di UPTD Griya Werdha Kota Surabaya tahun 2017 sebagian besar berada pada kelompok umur 60 - 74 tahun dan didominasi oleh lansia berjenis kelamin perempuan. Hampir semua lansia memiliki tingkat pendidikan yang rendah dan lansia paling banyak berstatus menikah. Lansia di UPTD Griya Werdha Kota Surabaya sebagian besar memiliki penyakit kronik yang diderita serta memiliki status hubungan sosial dan kualitas hidup yang buruk. Penelitian lebih lanjut didapatkan hasil bahwa terdapat hubungan antara interaksi sosial dengan kualitas hidup lansia dimana semakin baik interaksi sosial yang dimiliki lansia maka semakin tinggi kualitas hidup lansia tersebut (Sutikno, 2011)

Penelitian ini diharapkan bisa menjadi masukan untuk petugas UPTD Griya Werdha Kora Surabaya dalam meningkatkan kualitas hidup lansia dengan cara meningkatkan produktifitas lansia di panti seperti memberikan keterampilan pada lansia dengan mengadakan kegiatankegiatan positif yang dibutuhkan para lanjut usia yang meliputi pelatihan keterampilan dan kesempatan menyalurkan hobi, memperbanyak kegiatan-kegiatan untuk lansia agar interaksi sesama lansia meningkat, mengadakanscreeningsecara menyeluruh dengan rutin terhadap status kesehatan lansia untuk menunjang kesehatan fisik lansia yang optimal mengingat dari hasil penelitian banyak lansia yang memiliki penyakit kronis dan mengadakan penyuluhan tentang masa tua untuk memberikan informasi-informasi yang harus diperhatikan dan dipersiapkan lansia untuk menghadapi masa tua yang berkualitas.

\section{DAFTAR PUSTAKA}

Andesty, D. 2017. Faktor yang Berhubungan dengan Kualitas Hidup Lanjut Usia (Lansia) di Panti Griya Werdha Kota Surabaya. Skripsi. Surabaya: Universitas Airlangga 
Azwan, Herlina, dan Karim,D. 2015. Hubungan Dukungan Sosial Teman Sebaya dengan Kualitas Hidup Lansia di panti Sosial Tresna Werdha. JOM, vol 2(2): pp. 962970.

Badan Kependudukan Keluarga Berencana Nasional. 2012. Pembinaan Mental Emosional Bagi Lansia. Jakarta: Direktorat Bina Ketahanan Keluarga Lansia dan Rentan.

BPS. 2016. Profil penduduk lanjut Usia Provinsi Jawa Timur. Surabaya: BPS Provinsi Jawa Timur

Darmojo, B. 2009. Buku Ajar Geriatri: Ilmu Kesehatan Usia Lanjut. Jakarta: Balai Penerbit Fakultas Kedokteran Universitas Indonesia

Demartoto, A. 2007. Pelayanan Sosial Non Panti Bagi Lansia (Suatu kajian Sosiologis). Surakarta: UNS Press.

Estelle, J.J., Kirsch, N.L., and Pollack, M.E. 2006. Enhancing Social Interaction In Elderly Communities Via Location- Aware Computing. CBI Journal.

Hardywinoto dan Setiabuhi, T. 2005. Panduan Gerontologi: Tinjauan Dari Berbagai Aspek. Jakarta: PT Gramedia Pustaka Utama.

Kaplandan Saddock. 2007. Sinopsis Psikiatri Alih Bahasa. Jakarta: Binarupa Aksara.

Kemenkes RI. 2011. Kecakapan dan Pengasuhan Lansia. Jakarta: Depkes RI.

Kemenkes RI. 2013. Buletin Jendela Data dan Informasi Kesehatan. Jakarta: Kemenkes RI.

Kemenkes RI. 2015. Pusat Data dan Informasi Kementerian Kesehatan RI Situasi dan Analisis Lanjut Usia. Jakarta: Kemenkes RI.

Kemenkes RI. 2016. Pusat Data dan Informasi Kementerian Kesehatan RI Situasi dan Analisis Lanjut Usia. Jakarta: Kemenkes RI

Maryam, R.S., Ekasari, M.F., Rosidawati, et al. 2008.Mengenal Usia Lanjut dan Perawatannya. Jakarta: Penerbit Salemba Medika

Mubarak, W. I. dan Susanto, B. A. 2006. Buku Ajar Keperawatan Komunitas 2: Teori dan Aplikasi dalam Praktik dengan Pendekatan Asuhan Keperawatan Komunitas, Gerontik dan Keluarga. Jakarta: Sagung Seto

Notoadmojo, S. 2008. Kesehatan Masyarakat Ilmu dan Seni. Jakarta: PT. Rineka Cipta.

Noorkasiani, T. S. 2009. Kesehatan Usia Lanjut dengan Pendekatan Asuhan Keperawatan. Jakarta: Salemba Medika.

Nugroho, W. 2008. Keperawatan Gerontik dan Geriatrik. Jakarta: EGC.

Potter, P. A. dan Perry, A. G. 2005. Fundamental of Nursing:Consepts, Process, and Practice (4thedition). St Louis, MI: Elsevier Mosby.

Putri, S.T., Fitriana, L.A., dan Ningrum,A. 2015. Studi Komparatif: Kualitas Hidup Lansia yang Tinggal Bersama Keluarga dan Panti. Jurnal Pendidikan Keperawatan Indonesia, vol. 1: pp. 1-6.

Rantepadang, A. 2012. Interaksi Sosial Dan Kualitas Hidup Lansia Di Kelurahan Lansot Kecamatan Tomohon Selatan. JKU, Vol. 1, No. 1, Juni 2012, 1(1): pp. 1-9.

Rawiyah, U. 2014. Perbedaan Kualitas Hidup Manula Pengguna dan bukan Pengguna Gigi Tiruan Penuh di Kota Makassar. Makassar: Universitas Hasanuddin

Salamah. 2005. Kondisi Psikis Dan Alternatif Penanganan Masalah Kesejahteraan Sosial Lansi Di Panti Wredha. Jurnal PKS Vol. IV: pp.55-61.

Samper, T. P., Pinontoan, O. R., dan Katuuk, M. E. 2017. Hubungan Interaksi Sosial dengan kualitas Hidup Lansia di BPLU Senja Cerah Provinsi Sulawesi Utara.e-Journal Keperawatan $\quad(e-K P): \quad \mathrm{Vol}$ 5(1):pp.1-9. 
Sanjaya, A., dan Rusdi, I. 2012. Hubungan Interaksi Sosial Dengan Kesepian Pada Lansia. Jurnal Keperawatn Holistik, Vol. 1(3): pp.26-31.

Sastroasmoro, S., dan Ismael, S. 2010. Dasar-dasar metodologi penelitian klinis. Edisi ke-3. Jakarta: Sagung Seto.

Siregar, S.F., Arma, A.J.A., dan Lubis, R.M. 2013. Perbandingan Kualitas Hidup Lanjut usia yang Tinggal di Panti Jompo dengan yang Tinggal di Rumah di Kabupaten Tapanuli Selatan tahun 2013. Gizi, Kesehatan Reproduksi dan Epidemiologi, vol. 2(6): pp.1-9.

Supraba, N. P. 2015. Hubungan Aktivitas Sosial, Interaksi Sosial, dan Fungsi Keluarga dengan Kualitas Hidup Lanjut Usia di Wilayah Kerja Puskesmas I Denpasar Utara Kota Denpasar. Tesis. Bali: Universitas Udayana Denpasar

Suprajitno. 2004. Asuhan Keperawatan Keluarga : Aplikasi dalam praktik. Jakarta: EGC

Suriastini, N.W., Sikoki, B.S., Rahardjo, T.W., et al. 2013. Satu Langkah
Menuju Impian Lanjut Usia Kota Ramah lanjut Usia 2030 Kota Surabaya. Yogyakarta: SurveyMeter

Sutikno, E. 2011. Hubungan Antara Fungsi Keluarga Dan Kualitas Hidup Lansia. Jurnal Kedokteran Indonesia, Vol. 2(1): pp.73-79.

Wikananda, G. 2015. Hubungan Kualitas Hidup dan Faktor Resiko Pada Usia Lanjut Di Wilayah Kerja Puskesmas Tampaksiring I Kabupaten Gianyar Bali. Intisari Sains medis, vol.8(1): pp.41-49.

Yuliati, A., Baroya, N., dan Ririyanti, M. 2014. Perbedaan Kualitas Hidup Lansia yang Tinggal di Komunitas dengan di Pelayanan Sosial Lanjut Usia ( The Different of Quality of Life Among the Elderly who Living at Community and Social Services ). Jurnal Pustaka Kesehatan, vol 2(1):pp.87-94.

Yuli, R. 2014. Buku Ajar Asuhan Keperawatan Gerontik. Jakarta: Cv. Trans Info Media. 